\title{
Японский сад в России как пространство для межкультурного диалога: к 20 -летию истории создания сада дружбы Тояма-Владивосток
}

Во второй половине XX в. Япония стала уделять особое внимание популяризации своей культуры в мире. Активная деятельность по распространению информации о традиционных японских искусствах за рубежом способствовала формированию позитивного имиджа страны и преодолению межкультурного барьера, являющегося, по мнению известного буддолога Д.Т. Судзуки, причиной конфликтов между Востоком и Западом [4, с. 16]. Не осталась в стороне и сфера садостроительства. Реализация проектов японских садов за рубежкм предполагала межкультурное взаимодействие на разных уровнях: политическом, профессиональном, академическом, а также содействовала вовлечению иностранцев в процесс познания японской культуры. По данным исследования Токийского сельскохозяйственного университета, всего за пределами Японии было возведено 560 японских садов; по их количеству лидирует США (150), на втором месте - Китай (56), на третьем - Германия (36). Россия занимает 18 позицию (всего 6 садов) ${ }^{1}$ [11, с. 485].

Первым крупнейшим совместным проектом СССР и Японии, реализованным в 1987 г., был японский сад Главного ботанического сада им. Н.В. Цицина РАН в Москве, ставший уникальным местом знакомства с японскими традициями. В то же время этот сад, выполненный в натуралистическом стиле, иллюстрировал лишь одну из граней садового искусства Японии. Позднее, в 2001 г., во Владивостоке появился японский сад² другого типа - "сухой пейзаж" (карэсансуй), который значительно расширил представление россиян об этом феномене японской культуры (g6ото 1). Сад был построен по инициативе общества "Тояма-Владивосток" и его председателя Ё. Моримото 3 в рамках программы сотрудничества между Приморским краем и предектурой Тояма 4 . Авторы проекта стремились к тому, чтобы сад на долгие годы оставался воплощением дружбы двух народов и служил площадкой для межкультурного диалога. Однако за время эксплуатации объект стал постепенно утрачивать свои оригинальные черты, что привело к ослаблению его значения как символа Японии. В данной статье мы предлагаем впервые рассмотреть историю создания сада, определить его научно-образовательный потенциал, раскрыть идейно-образную концепцию, проанализировать меры поддержки и установить причины деформации художественного облика. Это поможет глубже понять

1 По состоянию на 01.09.2014 г.

2 Официальное название - Сад дружбы Тояма-Владивосток; другое название - Сад им. Моримото. Церемония открытия состоялась 31 августа 2001 г.

3 Моримото Ёсио (1915-2014) - японский предприниматель, генеральный директор и президент энергетической компании "Хокурику дэнрёку" (префр. Тояма), первый председатель общества "Тояма-Владивосток". Проект по строительству японского сада во Владивостоке финансировался лично председателем Ё. Моримото.

4 Соглашение о дружбе и сотрудничестве между Приморским краем (Россия) и префектурой Тояма (Япония) от 26 августа 1992 г.

(C) Мостовой C. А., Мостовая А. С., 2021

МОСТОВой Сергей Александрович, канд. ист. наук, член Союза дизайнеров России, учредитель и главный редактор "Yugen Landscape Journal" (2. Владивосток). E-mail: mostovojs@mail.ru

МОСТОВАЯ Анна Сергеевна, младший научный сотрудник, Тихоокеанского института географии ДВО РАН (2. Владивосток). E-mail: kartashema@gmail.com 


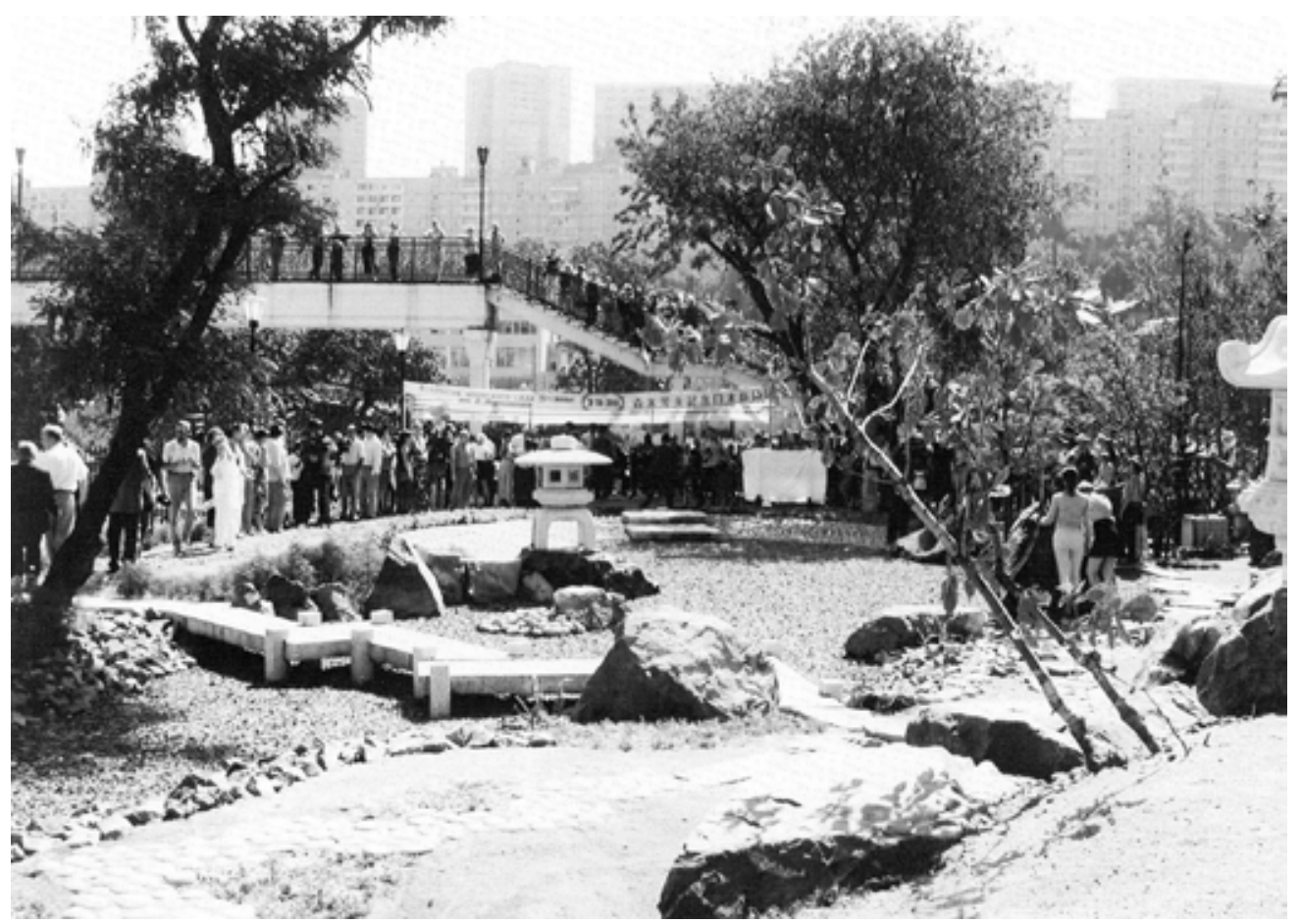

Фото 1. Церемония открытия сада дружбы Тояма-Владивосток 31 августа 2001 г. Источник: из архива Мостового С.А.

проблему функционирования материальных объектов японской культуры в России и оценить их значимость для развития международных отношений. Личное участие в реализации проекта позволило сформировать источниковую базу исследования, основанную на материалах, собранных в Японии, и регулярных натурных обследованиях сада.

Реализация проекта началась с поиска места сада доступного и открытого для горожан. Этим критериям соответствовал участок в северо-восточной части кампуса Владивостокского государственного университета экономики и сервиса (ВГУЭС), который согласился обеспечить сохранность сада и последующий уход за ним. Поблизости также находился мост дружбы Тояма-Приморье - символ добрососедских отношений между странами. Кроме того, осенью 2000 г. японские специалисты посетили Ботанический сад-институт ДВО РАН с целью ознакомления с местной коллекцией растений, отдельные виды которых планировалось использовать в озеленении сада.

Японская сторона осуществляла разработку архитектурного проекта сада, контроль над строительными работами, формирование профрессиональной команды и доставку необходимых материалов из преф. Тояма, а российская сторона отвечала за координацию работ во Владивостоке и привлечение подрядчиков (Инагаки, с. О проекте строительства японского сада, 2000. Из архива Мостового С.А.). В апреле 2001 г. на краткосрочную стажировку в преф. Тояма были направлены студенты ВГУЭС, которые впоследствии приняли участие в создании сада дружбы. В Японии студенты освоили практические навыки возведения традиционных садово-парковых элементов и ознакомились с дизайн-проектом будущего сада, разработанным компанией "Куго итидзюэн"5 (øбото 2). В истории вузов Приморского края подобная миссия проходила впервые. Международный колледж ремесла и искусства - одно из уникальных учебных заведений в Японии, занимающихся подго-

5 Садостроительная компания "Куго итидзюэн" была основана в г. Тояма (Япония) в 1875 г. Генеральный директор - Куго Синдзи, потомственный мастер садов, профессор Международного колледжа ремесла и искусства, преф. Тояма, Япония. 


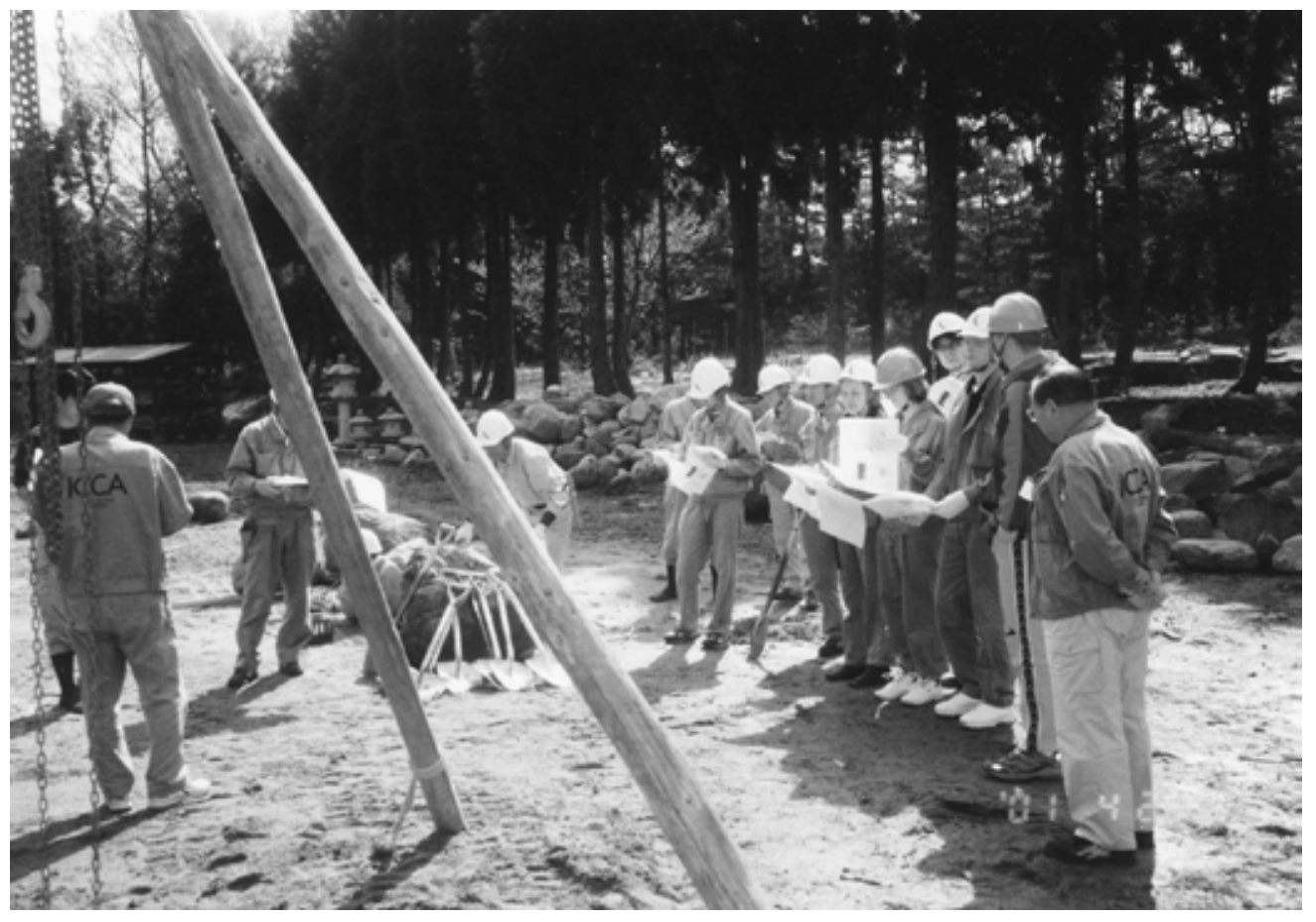

Фото 2. Практические занятия по установке камней в Международном колледже ремесла и искусства при участии стажёров из ВГУЭС, преф. Тояма, Япония, апрель 2001 г. Источник: из архива Мостового С.А.

товкой специалистов в области садостроительства и деревянного зодчества также впервые принимал стажёров из России, что вызвало высокий интерес у тоямской общественности $[5 ; 12 ; 13]$.

В мае 2001 г. во Владивостоке состоялась рабочая встреча руководителя проекта К. Канаока с ректором ВГУЭС, профр. Г. И. Лазаревым для заключительного обсуждения деталей по устройству сада [1]. К этому времени на территории университета от старых построек была расчищена площадка, на которую завезли природные камни общим весом около 20 т. Основные строительные работы продолжались с июня по июль. За этот период на объекте побывало 28 ландшафотных архитекторов-волонтёров из Ассоциации по озеленению, ландшафтной архитектуре и гражданскому строительству предр. Тояма. При их участии были установлены камни, вымощены дорожки, возведены малые архитектурные фрормы и высажены растения. Часть материалов и традиционные атрибуты японского сада - гранитные плиты, речной окатыш, каменные мосты и фонари, каменный сосуд для воды, бамбуковая изгородь были привезены из префр. Тояма, а природные камни и растения подобраны в Приморье.

Авторы концепции сада обратились к художественным принципам карэсансуй, суть которых заключается в абстрактном выражении морских и речных пейзажей. По этой причине в саду отсутствовала вода - её заменили камни, символизирующие знаменитые природные места региона Тояма - водопад Сёмёдаки в горах Татэяма и побережье Тоямского залива ${ }^{6}$ (фбото 3,4 ). Выбор на карэсансуй пал не случайно. Он широко известен в мире и ассоциируется исключительно с японскими садовыми традициями, к тому же сооружение "сухого" ландшафрта значительно быстрее и менее затратно по сравнению с созданием водных объектов. Стиль карэсансуй зародился в Японии ещё в XIV в. В его скрытых и отвлечённых образах таится суть японского духовно-

6 В 2014 г. Тоямский залив вошёл в "Клуб самых красивых заливов мира" - НПО, поддерживаемая ЮНЕСКО (входит 41 залив из 27 стран). Источник: https://world-bays.com. 

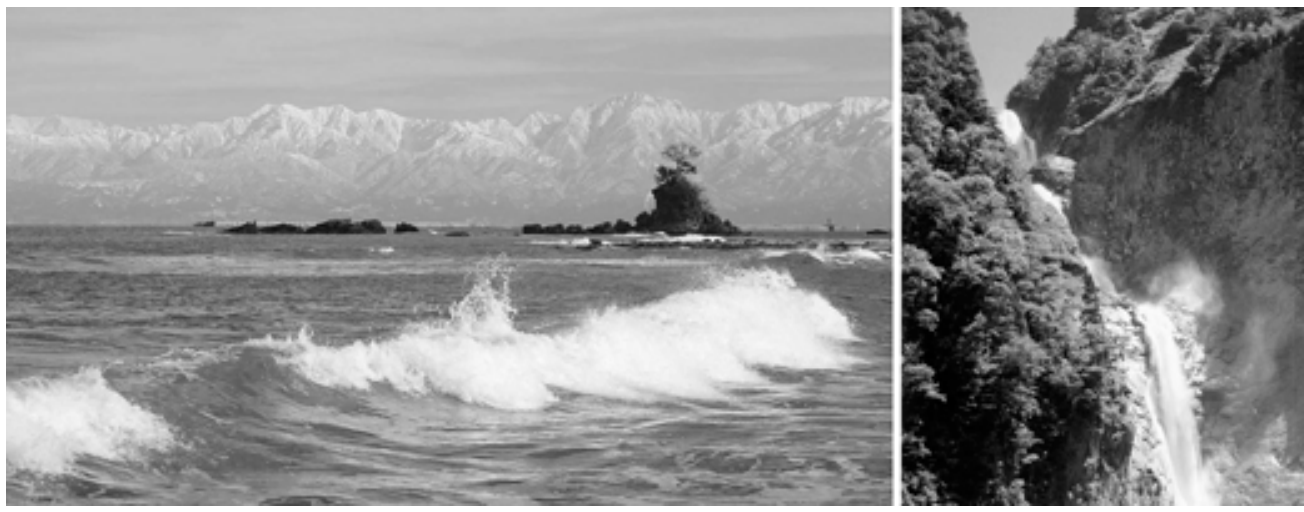

Фото 3, 4. Знаменитые пейзажи преф. Тояма:

(слева) горная цепь Татэяма, вид с побережья Амахараси. Источник:: nippon.com (справа) водопад Сёмёдаки в горах Татэяма. Источник: фото Мостового С.А.

го мировосприятия, сформированного восточными религиозно-фрилософрскими учениями, в частности дзэн-буддизмом, поэтому камень, помещённый в пространство японского сада, воспринимается не просто как пластичная форома, а как предмет религиозного осмысления мира. Для российского менталитета карэсансуй может показаться чужеродным и необычным, но если вдуматься в сюжет сада, то окажется, что в нём есть символы, близкие по духу и жителям Приморья - прибрежные ландшафты и каменистые пляжи Японского моря. По замыслу архитекторов, такая художественная интерпретация природных ландшафртов наглядно демонстрировала эстетические принципы японской культуры, в которой важное место занимает особое отношение к природным материалам - камню, воде, растениям.

Центральным әлементом композиции сада с развитой "сухой" структурой являлся водопад, из верховья которого стремились вниз два потока с разным характером течения: ниспадающий поток в виде гранитной плиты и горизонтальный поток в стиле ручья. Водопад впадал в пруд с западной стороны, а ручей с протяжённым извилистым руслом с северной стороны, замыкая общую водную систему ландшафта. Таким образом всё пространство делилось на две основные зоны - вертикальную и горизонтальную. Водопад вместе с многочисленными природными камнями, символизирующими горную гряду, составлял вертикальную часть ландшафрта, а "сухой" водоём, выраженный плоской насыпью гравия, мысами и каменистыми побережьями формировал горизонтальную часть ландшафта. В результате общая пейзажная картина сада воспринималась с главной видовой точки на каменистом пляже словно перспектива на просторы Тоямского залива на фоне высоких горных хребтов Татэяма.

При строительстве сада тоямские специалисты старались не отступать от проекта и следовать намеченным идеям максимально точно, однако сопоставление его планировки на момент окончания строительства с архитектурными чертежами выявило ряд несоответствий первоначальному замыслу: была изменена схема установки камней и сокращён дендрологический состав. В частности, фррагменты опорных стен за чашей для омовения (цукубаи) и пьедестальным фонарём (касугадоро) были укреплены массивными камнями, хотя первоначально там планировалось ограждение в виде кладки из небольших камней. Изрезанный береговой контур северной части водоёма значительно упростился из-за применения речного окатыша (по проекту предполагались продолговатые природные камни). Вместо крупного природного валуна плоской формы на краю каменистого пляжа использовали расколотую надвое гранитную плиту, аналогичную той, что имитирует ниспадающий поток водопада. А отдельные шаговые камни (тобииси), ведущие от центрального входа до чаши для омовения, заменили гравием. Кроме того, отсутствовали предусмотренные в проекте насаждения магнолии, абрикоса, можжевельника даурского, микробиоты, рододендронов и др. Задний план центральной камен- 


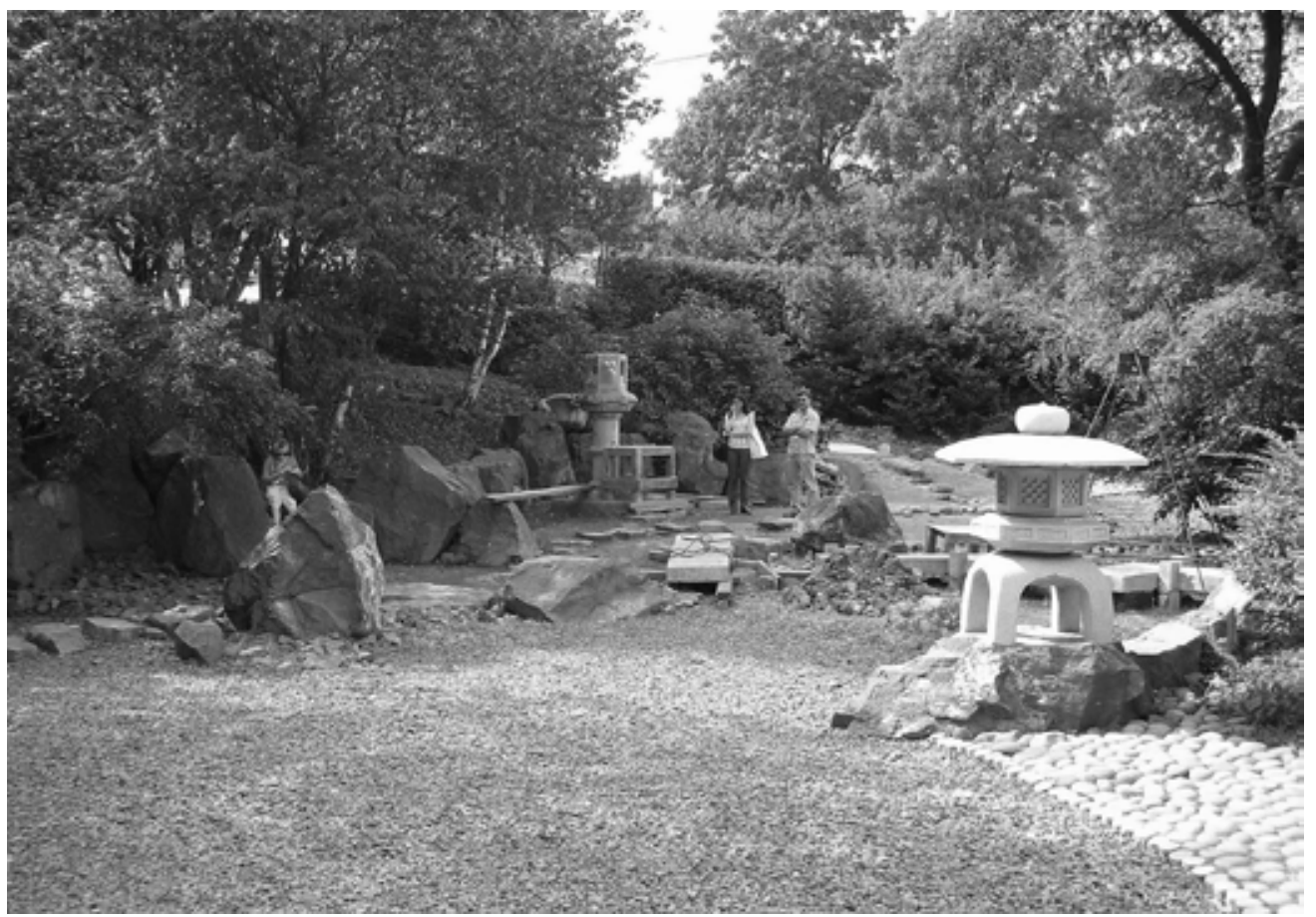

Фото 5. Сад дружбы во время реконструкции пьедестального каменного фонаря и каменного моста, август 2010 г. Источник: фрото Мостового С.А.

ной композиции водопада намеревались сформировать с помощью большого количества елей, но в итоге они были замещены смешанными посадками других хвойных и широколиственных пород. Причинами подобных отступлений стали сложности с подбором необходимого ассортимента природного камня и древесных насаждений, а также сжатые сроки строительства. Архитекторы, несмотря на трудности, смогли реализовать проект без существенного ущерба для ландшафртной эстетики, хотя, несомненно, воплощение первоначальных идей позволило бы ярче подчеркнуть характер японского сада.

За двадцать лет эксплуатации сада каменная структура ландшафрта осталась практически неизменной, однако значительно пострадали малые архитектурные формы и древесные насаждения. В 2003 г. сотрудники ВГУЭС восстановили фонарь для любования снегом (юкимидоро), испорченный вандалами после поражения нашей нащиональной сборной в матче со сборной Японии на чемпионате мира по фрутболу в 2002 г. Для надёжности всей конструкции полностью разрушенную деталь фонаря, которая поддерживает крышу и традиционно имеет полую форму с отверстием для свечи, заменили на новую, изготовленную по специальному заказу из цельного куска гранита. В 2010 г. провели реставрацию пьедестального фонаря и зигзагообразного моста. Массивный фронарь высотой 3 м сильно накренился под собственной тяжестью и разрушился из-за недостаточно уплотнённого грунта, поэтому важной задачей стало сооружение фрндамента с использованием цемента и камней; для устранения деформации каменного моста под гранитные плиты возвели дополнительные усиленные опоры (фбото 5). С момента открытия сада регулярно проводились работы по удалению погибших растений и посадке новых видов, в ландшафте появились пихты цельнолистная и белокорая, тис остроконечный, рододендроны, курильский чай и др. $К$ важным мерам следует отнести и обновление верхнего слоя гравия, что значительно улучшило эстетический облик "сухого пейзажа"7.

7 Гравий в садах карэсансуй имеет особое значение. В Японии самым распространенным видом гравия считается образец из реки Сиракава в Киото (либо его аналоги), фракцией 5-10 

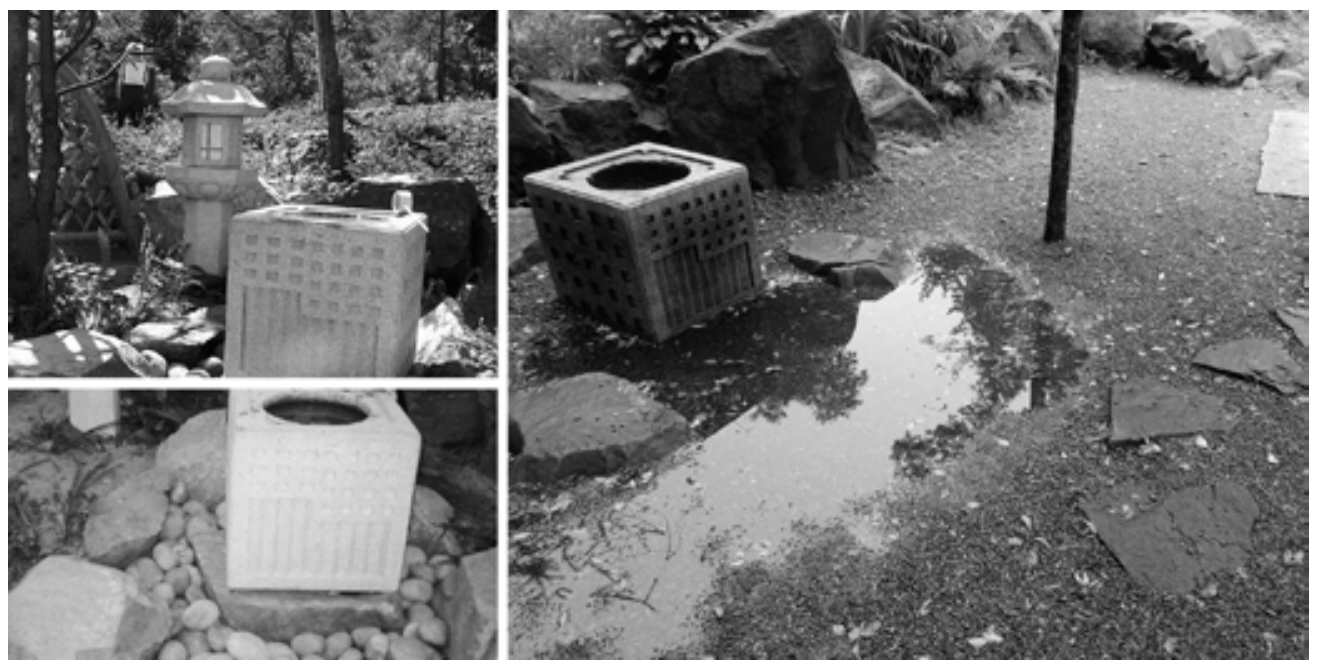

Фото 6, 7. Чаша для омовения (цукубаи):

(слева) первоначальное состояние, сентябрь 2001 г. Источник: из архива Мостового С.А.; (справа) текущее состояние, июнь 2020 г. Источник: фото Мостового С.А.

Принятые меры позволили сберечь базовую структуру сада, но для формирования полноценного облика были недостаточными. Решение этой задачи требует тщательного анализа ландшафтной планировки, понимания роли и значения её деталей. Основная цель поддержания сада - сохранить смысловую и композиционную целостность пейзажной структуры, составляющие элементы которой организованы по строго определенным правилам и неразрывно связаны между собой, поэтому следует учитывать такие важные принципы японского сада, как размещение деревьев в соответствии с их ролью в ландшафте (якубоку ${ }^{8}$ ) и эффрект направленной перспективы, когда из отдельной видовой точки взгляд фокусируется на выделяющемся элементе ландшафта [8, с. 70-71]. В процессе ухода за садом необходимо избегать произвольного перемещения, деформации или разрушения ключевых элементов, иначе может размыться фокус перспективы, сместиться баланс композиции и потеряться связь с остальными элементами.

По данным исследования Японского института ландшафтной архитектуры, главная причина запущенного состояния зарубежных японских садов заключается в отсутствии должного ухода за растениями и правильной dpopмовки кроны, а также в самовольном замещении одного вида насаждений другими. Ответственные за сад сотрудники часто действуют по своему усмотрению, пренебрегая технологиями, принятыми в Японии, что неизбежно приводит к искажению облика японского сада [7]. Похожая ситуация сложилась с садом дружбы. Из крупномеров погибли почти все хвойные растения; многие деревья росли бесконтрольно, не подвергаясь формированию, в результате образовались пустынные пространства, нарушился композиционный баланс и изменилось общее восприятие пейзажа. Это особенно заметно на примере западной части сада, где не сохранилась группа сосен, которая олицетворяла горный ландшафот и составляла эстетическую основу заднего плана композиции водопада. Основной причиной гибели крупномеров является болезненная адаптация в условиях высокой загазованности и запылённости: сад

мм, обладающий округлой формой и выразительной текстурой светло-серого оттенка. При строительстве японских садов за рубежом местный материал стараются подбирать именно по этому образцу.

8 Якубоку - букв. "дерево, исполняющее роль". Впервые термин упоминается в источнике "Цукияма тәйдзодән", в садовом трактате XVIII в. Среди наиболее распространенных примеров - сёсинбоку (главное дерево), кэйёбоку (дополнительное дерево), хисэндзавариноки (дерево, преграждающее водный источник), хидзавариноки (дерево, скрадывающее свет), хатиукэноки (дерево рядом с сосудом), хасимотоноки (дерево у моста) и др. 


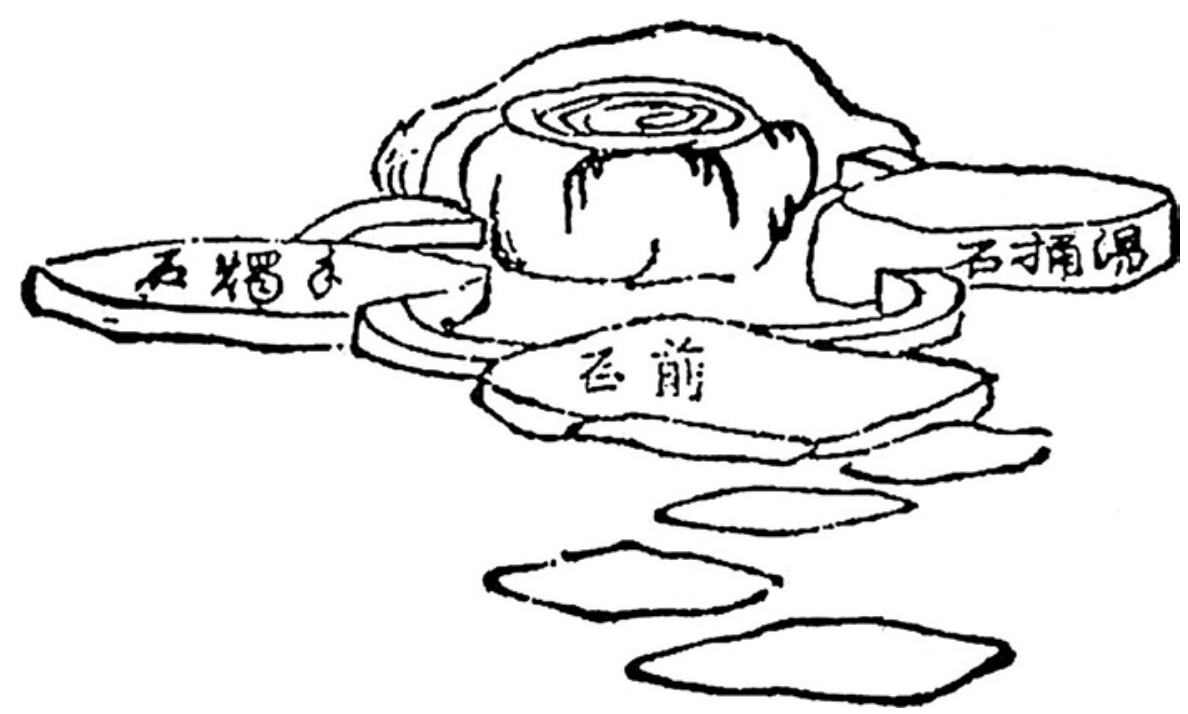

Рис. 1. Иллюстрация цукубаи из японского трактата по созданию садовых изгородей и каменных композиций, 1827 г. Источник: [9].

примыкает к крупной транспортной развязке и не имеет защитной зелёной полосы вдоль придорожной границы. По северной и восточной сторонам сада были дополнительно высажены пихты, которые в будущем сформируют заслон от дороги. В то же время высота пихт на северном склоне уже достигла уровня, когда за их кронами скрылся отдалённый вид на сад сакуры ${ }^{9}$. Таким образом нарушился принцип "заимствованного пейзажа" (сяккэй) ${ }^{\mathbf{1 0}}$ и сократилась глубина визуального пространства сада.

На краю каменистого пляжа сохранилась отдельностоящая сосна, наделённая особой ролью в ландшафте. Её оригинальный силуэт с изогнутым стволом и сформированной по традиционным канонам кроной должен был стать композиционной доминантой, просматриваемой с разных видовых точек. Размещение сосны было тщательно продумано в соответствии с принципами айстоп (англ. eyestop) ${ }^{11}$ и "показывать, скрывая" (лиэгакурэ) ${ }^{\mathbf{1 2}}-$ с центрального входа взгляд беспрепятственно фокусировался на её кроне, которая в то же время являлась визуальной преградой для отдалённой перспективы сада. В конечном счёте сосна осталась не сформированной, а её внешний вид и болезненное состояние совершенно не соответствуют заявленной роли. Ситуация усугубилась тем, что во время обновления древесных насаждений на

9 Сад сакуры был основан в 2004 г. поблизости от сада дружбы из саженцев вишни Саржента, привезенных из Японии, в рамках продолжения исполнения программы развития двусторонних отношений преф. Тояма и Приморского края.

10 Сяккэй, букв. "заимствованный пейзаж" - принцип, суть которого заключается в специальном включении в пейзажную структуру сада отдаленного вида, самостоятельного природного пейзажа. Заимствованными пейзажами могут быть горы, поля, архитектурные сооружения и т.д., расположенные за пределами сада. Включение отдаленного пейзажа позволяло визуально расширить пространство сада, сделать его восприятие динамичным и органично связать с местностью.

11 Айстоп (англ. eyestop) - способ расстановки деревьев, обладающих выразительным силуэтом или другими уникальными качествами, которые легко фокусируют на себе рассеянный взор зрителя, потому что находятся прямо у него на пути.

12 Миэгакурэ - букв. "показывать, скрывая", принцип, при котором ландшафтное пространство не раскрывается сразу целиком, а открывается постепенно с помощью чередования пейзажных видов по спланированному сценарию пространственного перемещения. Достигается путем особой организации рельефа и пешеходной сети, использования объектов, заслоняющих другие объекты или отдаленные виды, и т.д. Позволяет достичь әффекта глубины пространства и сформировать психологическую заинтересованность у посетителя к созерцанию всего сада. 


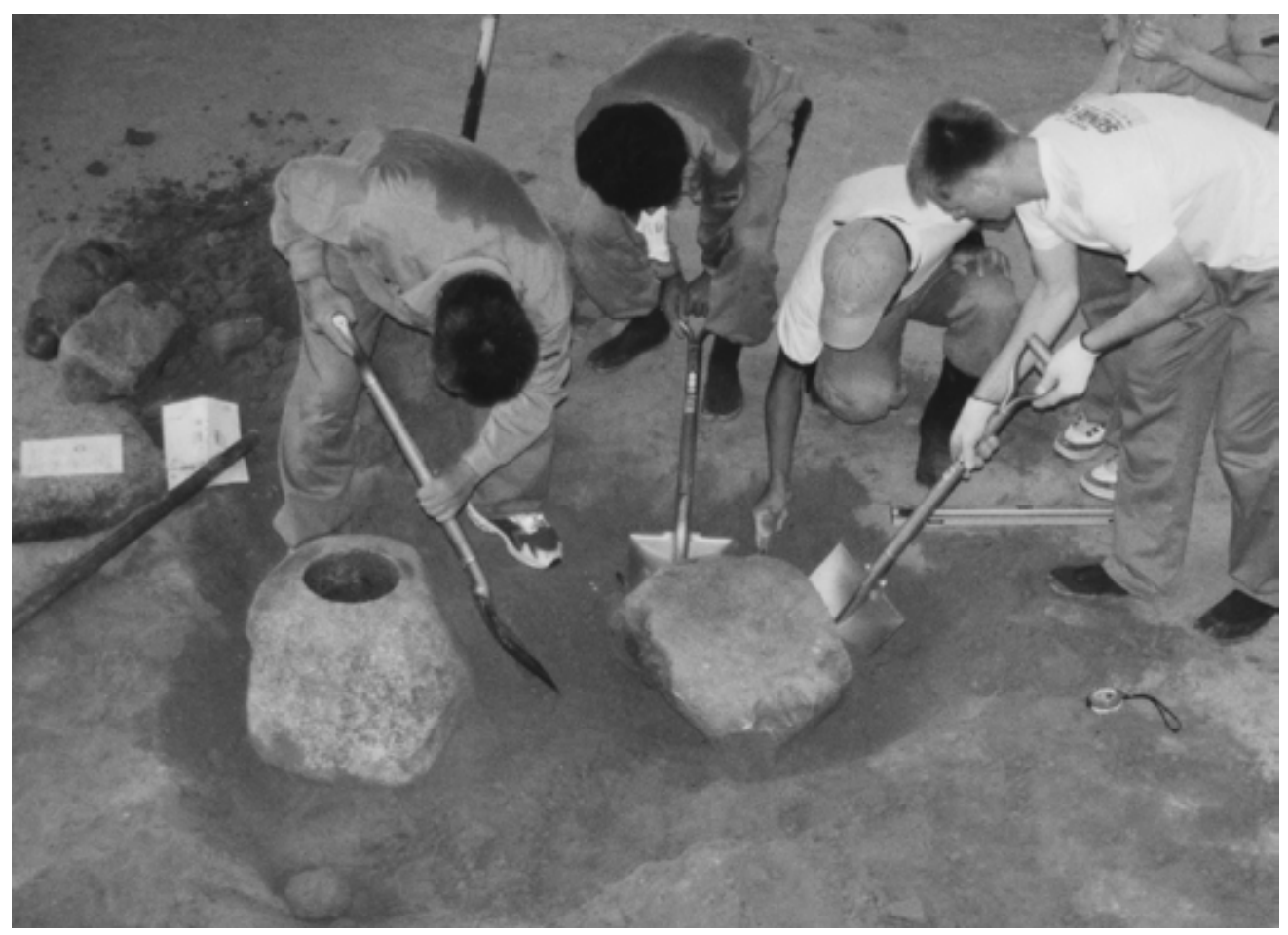

Фото 8. Установка цукубаи при участии стажёра из ВГУЭС на практических занятиях в Международном колледже ремесла и искусства, преф. Тояма, Япония, сентябрь 2002 г.:

(слева) сосуд для воды, (справа) камень маэиси. Источник: из архива Мостового С.А.

месте погибшего клёна по соседству с этой сосной внедрили пихту, что привело к нарушению композиционного баланса, основанного на сочетании хвойных и широколиственных пород, и доминантная роль сосны (aŭcmon) была утрачена.

Среди других причин, негативно влияющих на облик японского сада, можно выделить нарушение принципов использования таких важных атрибутов, как чаша для омовения (иукубаи) (g6ото 6,7$)$. Традиционно это устройство, представляющее собой каменный сосуд с водой и несколькими камнями, используется в чайных садах (родзи), где ритуал очищения перед чайной церемонией играет важную роль. Цукубаи часто встречается в садах другого типа как отдельный декоративный элемент, при этом его конструкция строго соответствует требованиям чайного сада. За время эксплуатации сада дружбы цукубаи постепенно утратил свои традиционные черты и из сложного устройства превратился в обычный сосуд. Для иукубаи тоямские мастера выбрали кубический сосуд с характерным геометрическим узором (Гинкакудзи-гата ${ }^{13}$ ). По обеим сторонам от него разместили камни для светильника (тэсёкуиси) и для кадки с горячей водой (юокэиси), а за ним - "задний камень" (усироиси), которые сохранились по сей день. Однако камень, установленный перед сосудом (лаэиси), исчез. Этот камень необходим не только в практических целях, но и как главный элемент, композищионно связывающий сосуд с общей пешеходной сетью из шаговых камней (тобииси), о чём свидетельствует японский письменный источник "Руководство по созданию садовых изгородей и каменных композиций" (1827), согласно которому камень маэиси задает начало дорожки тобииси (рuс. 1) [9, с. 58]. При строительстве цукубаи сразу после установки сосуда укладывают передний камень, т.к. он является ориентиром по высоте для остальных камней, включая тобииси (фото 8). Камень должен

13 Гинкакудзи-гата - форма каменного сосуда, заимствованная из образца в храме Серебряного павильона (Гинкакудзи), г. Киото. 


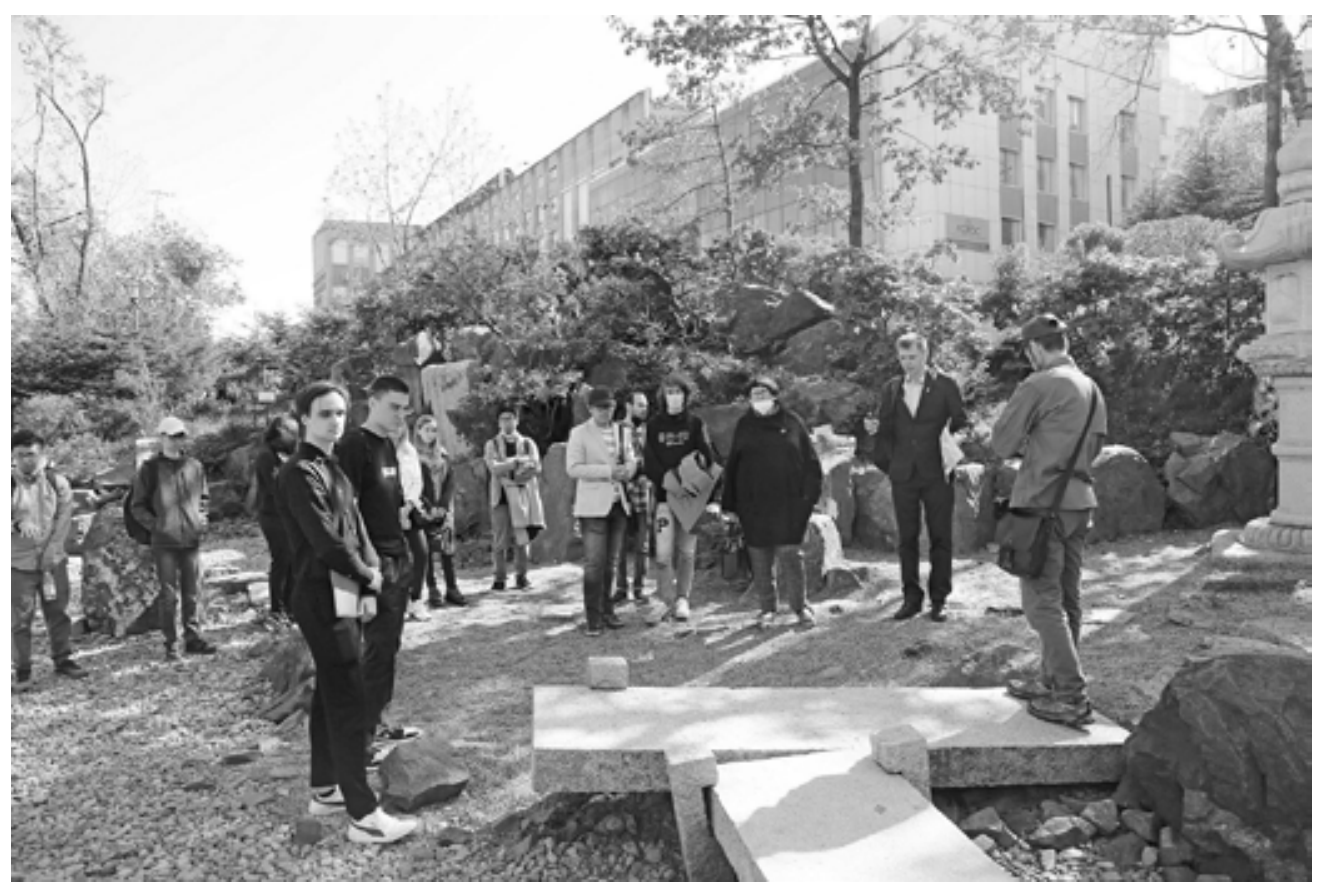

Фото 9. Экскурсионная часть открытой лекции Мостового С.А. о саде дружбы Тояма-Владивосток в рамках проведения программы "Года японо-российских межрегиональных и побратимских обменов (2020-2021 гг.)", ВГУЭС, г. Владивосток, 18 мая 2021 г. Источник: Фото Ещенко М., пресс-служба ВГУЭС.

быть плоским и немного выступать от поверхности земли, чтобы посетитель мог встать на него и наклониться к ёмкости с водой.

Изначально сосуд был установлен на камень-пьедестал, а углубление под ним выложено крупной галькой (дренаж). Позднее это углубление было засыпано мелким гравием, и теперь складывается ощущение, что он стоит прямо на земле $\mathrm{e}^{\mathbf{1 4}}$. В результате вырубки сухостоя пространство вокруг цукубаи стало открытым, что не соответствует атмосфере уединённого природного уголка, свойственного стилю родзи. Традиционно сосуд окружают невысокими теневыносливыми и влаголюбивыми растениями (папоротник, фрарфугиум японский и др.), и рядом обязательно располагают дерево, ветви которого склоняются над сосудом (принцип якубоку). Эти ветви вместе с деревьями, высаженными по сторонам, создают әффект "рамки", с помощью которого сосуд становится точкой зрительного фокуса [10, с. 288]. Завершённый вид чаше омовения придаёт чистая вода, которую либо постоянно меняют, либо обеспечивают её непрерывную подачу по водопроводу из бамбуковых труб. В редких случаях при отсутствии воды ёмкость заполняют мелким гравием ${ }^{15}$. В первое время в саду слева от камня тәсёкуиси находилась лиственница, справа от камня юокэиси - клён, а вокруг чаши росли папоротники, но со временем растения погибли. Примечательно, что посетители, незнакомые с японской культурой, часто принимали пустую чашу для омовения за урну и бросали в неё мусор. Вернуть первоначальный облик и смысл одному из важных атрибутов японского сада может реставрация цукубаи в соответствии с традиционны-

14 В японской садовой практике встречаются случаи, когда сосуд может стоять на земле без камня-пьедестала. Как правило, это распространяется на сосуды неправильной формы, выполненные из природного камня.

15 Такой прием встречается в одном из цукубаи императорской виллы Кацура-рикю в г. Киото. 
ми канонами. Все вышеизложенные замечания и рекомендации также могут быть учтены при разработке комплекса мер по восстановлению сада.

Сад дружбы сыграл определённую роль в развитии и укреплении научно-культурных связей между Россией и Японией. После строительства сада в 2002 г. по инициативе японской стороны на углублённую стажировку по традиционному садоустройству в преф. Тояма был приглашён студент ВГУЭС. Обмен опытом в этой сфере положил начало научной деятельности, результатом которой стало появление первых на Дальнем Востоке России исследований по ландшафтному искусству Японии $[2 ; 3]$. Сегодня сад входит в состав университетского дендропарка, выполняющего научно-просветительские функции, и является значимым образовательным ресурсом при подготовке специалистов в области ботаники, экологии и дизайна (фото 9) [6]. Сад также стал неотъемлемой частью туристических маршрутов Владивостока и продолжает привлекать внимание гостей дальневосточной столицы. Сотрудничество между Приморским краем и преф. Тояма в формате ландшафтного благоустройства продолжилось. Так, в 2002 г. рядом с садом появилась клумба дружбы "Приморский край - Тояма", представленная сортовыми тюльпанами из преф. Тояма, а в 2004 г. был заложен сад сакуры.

В заключении отметим, что проект строительства сада дружбы потребовал реализации целого комплекса мероприятий и тесной международной кооперации. Сад дал возможность жителям Приморья прикоснуться к японской культуре, не покидая родного края, поэтому крайне важно не допустить искажения его канонического образа. Исследования показали, что японский сад очень чувствителен к неправильному уходу и требует от ответственных лиц хорошей теоретической и практической подготовки. Среди главных причин деформации художественно-эстетического облика сада были выделены отсутствие профессионального ухода за растениями, несоблюдение традиционных принципов, нарушение строительных технологий. В 2020 г. сад дружбы вошёл в программу Министерства земли, индраструктуры, транспорта и туризма Японии по восстановлению японских садов за рубежом, так что впереди предстоит большая работа по его реставрации [14]. Активное сотрудничество с японскими специалистами в области ландшафтного строительства будет способствовать дальнейшему развитию научно-культурных связей между двумя странами.

\section{Литература}

1. Калиберова Т. Каменный фонарь в японском садике // Владивосток. 2001. 21 мая, № 75 (2688). С. 19.

2. Мостовой С.А., Павлова А.С. Ландшафртное искусство Японии: Истоки, традиции, современность. Владивосток: Дальнаука, 2010. 260 с.

3. Мостовой С.А. Эволюция японского сада в контексте национальной истории: автореферат дис. ... кандидата исторических наук: 07.00.03. Владивосток, 2016. 25 с.

4. Скворцова Е.Л. О культурологических воззрениях Нисиды Китаро // Вестник культурологии. 2019. № 1(88). С. 15-33.

5. Шелковникова О. Сад камней разобьют у ВГУЭСа // Конкурент. 2001. 22-27 мая, № 19 (527). С. 22.

6. Якименко Л.В., Иваненко Н.В. Эколого-образовательный потенциал дендропарка Владивостокского государственного университета экономики и сервиса (ВГУЭС) // Азимут научных исследований: педагогика и психология. 2018. Т. 7. №4 (25). C. 268-272.

7. Yamada T. Construction practice - 4. Maintenance - 2 // The Japanese Garden outside of Japan. Research Report (English Edition, 2007), Japanese Institute of Landscape Architecture. P. 41-43, [Электронный pecypc]. URL: https://www.jila-zouen.org/journal/ overseasjgardens (дата обращения: 26 июня 2020).

8. 相川貞晴. 庭園植栽施工 (Аикава С. Посадка растений в японском саду). 東 京:加島書店 (Токио: Кадзимасётән), 1990. 183 c.

9. 石組園生八重垣伝解説 (Руководство по созданию садовых изгородей и каменных композиций с комментариями) / 上原敬二編. 東京:加島書店 (под ред. К. Уэхара. Токио: Кадзимасётән), 1971. 108 с.

10. 輿水晶子, 半田陵子, 斉藤哲郎編集. 緑のデザイン図鑑 : 配植のテクニックと作 庭の手法: 樹木・植栽・庭づくり (Косимидзу А., Ханда Р., Сайто Т. Растения в садовом 
дизайне: приёмы размещения растений и принщипы создания садов). 東京: 建築知識 (Токио: Кэнтику тисики), 1998. 462 с.

11. 牧田直子, 鈴木誠. 海外の姉妹都市日本庭園の歴史と日本側自治体から見た 現状と課題 (Макита Н., Судзуки М. Проблемы и современное состояние японских садов за пределами Японии, которые были созданы в рамках побратимских отношений между городами: взгляд со стороны японских органов самоуправления) // ランドスケー プ研究 (Рандосукэпу кэнкю). 2015. №78 (5). С. 483-486.

12. 日本庭園造りに意欲 (Стремление к созданию японского сада) // 富山新聞 (Тояма симбун). 2001. 27 апреля. С. 18.

13. ロシアで日本庭園造成へ (К строительству японского сада в России) // 富山新 聞 (Тояма симбун). 2001. 21 апреля.

14. 令和 2 年度海外日本庭園再生プロジェク卜の実施について (Относительно peaлизации проектов по восстановлению японских садов за рубежом в 2020 г.) // 国土交通 省 (Министерство земли, инфраструктуры, транспорта и туризма), 21.04.2020, [Электронный pecypc]. URL: https://www.mlit.go.jp/toshi/park/toshi_parkgreen_fr_000038. html (дата обращения: 12.06.2020).

\section{Транслитерация по ГОСТ 7.79-2000 система Б}

1. Kaliberova T. Kamennyj fonar' v yaponskom sadike // Vladivostok. 2001. 21 maya, № 75 (2688). S. 19.

2. Mostovoj S.A., Pavlova A.S. Landshaftnoe iskusstvo YAponii: Istoki, traditsii, sovremennost'. Vladivostok: Dal'nauka, 2010. $260 \mathrm{~s}$.

3. Mostovoj S.A. EHvolyutsiya yaponskogo sada v kontekste natsional'noj istorii: avtoreferat dis. ... kandidata istoricheskikh nauk: 07.00.03. Vladivostok, 2016.25 s.

4. Skvortsova E.L. O kul'turologicheskikh vozzreniyakh Nisidy Kitaro // Vestnik kul'turologii. 2019. № 1(88). S. 15-33.

5. SHelkovnikova O. Sad kamnej razob'yut u VGUEHSa // Konkurent. 2001. 22-27 maya, № 19 (527). S. 22.

6. YAkimenko L.V., Ivanenko N.V. EHkologo-obrazovatel'nyj potentsial dendroparka Vladivostokskogo gosudarstvennogo universiteta ehkonomiki i servisa (VGUEHS) // Azimut nauchnykh issledovanij: pedagogika i psikhologiya. 2018. T. 7. №4 (25). S. 268-272.

7. Yamada T. Construction practice - 4. Maintenance - 2 // The Japanese Garden outside of Japan. Research Report (English Edition, 2007), Japanese Institute of Landscape Architecture. P. 41-43, [EHlektronnyj resurs]. URL: https://www.jila-zouen.org/ journal/overseasjgardens (data obrashheniya: 26 iyunya 2020).

8. 相川貞晴. 庭園植栽施工 (Aikava S. Posadka rastenij v yaponskom sadu). 東京: 加島書店 (Tokio: Kadzimasyotehn), 1990.183 s.

9. 石組園生八重垣伝解説 (Rukovodstvo po sozdaniyu sadovykh izgorodej i kamennykh kompozitsij s kommentariyami) / 上原敬二編. 東京:加島書店 (pod red. K. Uehkhara. Tokio: Kadzimasyotehn), 1971. $108 \mathrm{~s}$.

10. 輿水晶子, 半田陵子, 斉藤哲郎編集. 緑のデザイン図鑑 : 配植のテクニックと作 庭の手法: 樹木・植栽・庭づくり (Kosimidzu A., KHanda R., Sajto T. Rasteniya v sadovom dizajne: priyomy razmeshheniya rastenij i printsipy sozdaniya sadov). 東京: 建築知識 (Tokio: Kehntiku tisiki), 1998. 462 s.

11. 牧田直子, 鈴木誠. 海外の姉妹都市日本庭園の歴史と日本側自治体から見た 現状と課題 (Makita N., Sudzuki M. Problemy i sovremennoe sostoyanie yaponskikh sadov za predelami YAponii, kotorye byli sozdany v ramkakh pobratimskikh otnoshenij mezhdu gorodami: vzglyad so storony yaponskikh organov samoupravleniya) //ランドスケープ研究 (Randosukehpu kehnkyu). 2015. №78 (5). S. 483-486.

12. 日本庭園造りに意欲 (Stremlenie k sozdaniyu yaponskogo sada) // 富山新聞 (Toyama simbun). 2001. 27 aprelya. S. 18.

13. ロシアで日本庭園造成へ (K stroitel'stvu yaponskogo sada v Rossii) // 富山新聞 (Toyama simbun). 2001. 21 aprelya.

14. 令和 2 年度海外日本庭園再生プロジェクトの実施について (Otnositel'no realizatsii proektov po vosstanovleniyu yaponskikh sadov za rubezhom v 2020 g.) // 国土交 通省 (Ministerstvo zemli, infrastruktury, transporta i turizma), 21.04.2020, [EHlektronnyj resurs]. URL: https://www.mlit.go.jp/toshi/park/toshi_parkgreen_fr_000038.html (data obrashheniya: 12.06.2020). 
Мостовой С. А., Мостовая А. С. Японский сад в России как пространство для межкультурного диалога: $к 20$-летию истории создания сада дружбы Тояма-Владивосток.

На примере японского сада (известного как "Сад дружбы Тояма-Владивосток"), построенного в 2001 г. во Владивостоке в рамках программы развития межкультурных связей между преф. Тояма и Приморским краем, анализируется проблема функционирования материального объекта японской культуры в России. Выделяются этапы реализации проекта, раскрывается ключевая идея сада, выявляются структурные изменения ландшафттной композиции и рассматриваются фокторы негативного воздействия на её культурный облик. Приводятся меры по восстановлению сада за период его эксплуатации и анализируется роль сада в развитии научно-культурных связей между странами.

Ключевые слова: межкультурные комлуникации, сад калней, садовопарковое строительство, японская культура, японский сад

Mostovoj S. A., Mostovaya A. S. Japanese garden in Russia as a space for intercultural dialogue: a case study about 20 years history of The ToyamaVladivostok Friendship Garden.

The paper discusses the construction and operation of Japanese garden, a traditional phenomenon of Japanese culture, outside Japan and discusses the case study of ToyamaVladivostok Friendship Garden (also known as Morimoto Garden) located in Vladivostok, Russia. This stone garden appeared in 2001 as a result of international cooperation between the regional governments of Toyama prefecture and Primorsky region. The paper highlights the main periods of construction and renovation, explains the key ideas and concepts of classical dry landscape garden (karesansui), defines the structural changes of the landscape composition and determines the negative factors that had impaired the appearance of the garden significantly.

Key words: international relations, Japanese culture, Japanese garden, landscape construction, stone garden

Для цитирования: Мостовой С. А., Мостовая А. С. Японский сад в России как пространство для межкультурного диалога: к 20-летию истории создания сада дружбы Тояма-Владивосток // Ойкумена. Регионоведческие исследования. 2021. № 4. C. 110-121. DOI: 10.24866/1998$6785 / 2021-4 / 110-121$

For citation: Mostovoj S. A., Mostovaya A. S. Japanese garden in Russia as a space for intercultural dialogue: a case study about 20 years history of The Toyama-Vladivostok Friendship Garden // Ojkumena. Regional researches. 2021. № 4. P. 110-121. DOI: 10.24866/1998-6785/2021$4 / 110-121$ 